\title{
Testosterone level, nasal gland volume and Leydig cell morphometry in capybaras (Hydrochoerus hydrochaeris)
}

\author{
[Niveis de testosterona, volume da glândula nasal e morfometria das células de Leydig em capivaras (Hydrochoerus \\ hydrochaeris)] \\ D.S. Costa ${ }^{1}$, T.A.R. Paula ${ }^{2}$ \\ ${ }^{1}$ Faculdade de Medicina Veterinária - UFMS \\ Caixa Postal 549 \\ 79070-900 - Campo Grande, MS \\ ${ }^{2}$ Departamento de Veterinária - UFV - Viçosa, MG
}

\begin{abstract}
The testosterone levels with nasal gland volume and Leydig cell morphometry in sexually mature capybaras were compared using 10 adult capybaras, aging 28 months. Body and testicular weight were $50 \mathrm{~kg}$ and $28 \mathrm{~g}$, respectively. The gonadosomatic index was $0.11 \pm 0.02 \%$, while nasal gland volume was $34.12 \pm 13.04 \mathrm{ml}$. Serum testosterone concentration was $25.07 \pm 14.73 \mathrm{ng} / \mathrm{ml}$. Leydig cell volume density and leydigosomatic index were, respectively, $28.8 \pm 8.3 \%$ and $0.030 \pm 0.007 \%$. Total and individual Leydig cell volumes were $6.88 \pm 1.92 \mathrm{ml}$ and $2,228.14 \pm 272.59 \times 10^{-12} \mathrm{ml}$, respectively. Leydig cell numbers per testis and per gram of testis were, respectively, $3,079.4 \pm 719.9 \times 10^{6}$ and $115.09 \pm 31.78 \times 10^{6}$ cells. These results show that increase in serum testosterone concentration is correlated to a proportional increase of nasal gland and Leydig cell volume in capybaras.
\end{abstract}

Keywords: capybara, testosterone, morphometry, Leydig cells, nasal gland

\section{RESUMO}

Estimaram-se as correlações entre os niveis de testosterona e o volume da glândula nasal e a morfometria das células de Leydig no parênquima testicular de capivaras sexualmente maduras. Utilizaram-se 10 capivaras com aproximadamente 28 meses de idade e com peso médio corporal de $50 \mathrm{~kg}$ e testicular de 28g. $O$ indice gonadossomático e o volume médio da glândula nasal foram $0,11 \pm 0,02 \%$ e

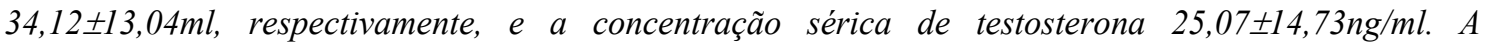
proporção volumétrica de células de Leydig e o indice leydigossomático foram 28,8 4 ,3\% e $0,030 \pm 0,007 \%$, respectivamente. Os volumes total e individual de células de Leydig foram 6,88 $\pm 1,92 \mathrm{ml}$ e $2228,14 \pm 272,59 \times 10^{-12} \mathrm{ml}$, respectivamente. O número de células de Leydig por testículo e por grama de testiculo foram, respectivamente, 3079,4 $\pm 719,9 \times 10^{6}$ e 115,09 $\pm 31,78 \times 10^{6}$. Concluiu-se que o aumento dos niveis séricos de testosterona foi acompanhado por aumento proporcional do volume da glândula nasal de capivaras e que a concentração desse hormônio é tanto mais alta quanto maior for o volume da célula de Leydig.

Palavras-chave: capivara, testosterona, morfometria, células de Leydig, glândula nasal

Recebido em 11 de abril de 2005

Aceito em 16 de maio de 2006

E-mail: deiler@nin.ufms.br 


\section{INTRODUCTION}

The capybara (Hydrochoerus hydrochaeris), a rodent with sub-aquatic habits, belongs to the sub-order Hystricognathi. It is noticeable within the sub-order because of its body weight, which is around $65 \mathrm{~kg}$, while other members, such as Myocastor coypus and Agouti paca, do not reach a quarter of this value.

Recently, the zootechnical potential of capybara began to be better exploited in Brazil, with studies about reproductive behavior and adaptation to captivity conditions (Lavorenti, 1989). Extensive joint production of bovines and capybaras results in minimum meat productivity values $(\mathrm{kg} / \mathrm{ha} /$ year) which are six times higher for capybaras (Alho, 1986). This high productivity is explained by the fact that, although efficiency in fiber food use and food conversion of capybaras is very similar to that of ruminants (Parra et al., 1978), they present higher reproductive efficiency than any other herbivorous of equal or larger size (Silva Neto, 1989).

The dominant male in a capybara familiar group has a nasal gland located on the snout dorsal surface. This ellipsoid gland produces abundant sebaceous secretion which is left on specific points when the animal rubs itself on bushes, trees and other objects to mark its territory (Paula, 1999; Costa et al., 2002).

Leydig cells are located in the intertubular compartment, where blood and lymphatic vessels, nerves and a diverse population of fibroblasts, macrophages and mastocytes can also be found (Setchell, 1991). The testosterone produced by Leydig cells is responsible for spermatogenesis as well as for the development and maintenance of male secondary sex characteristics (O'Donnel et al., 2001). This hormone is also responsible for patterns of behavior such as aggressiveness, territorial demarcation, social status for food capture and libido development (Hadley, 1988).

A number of the basic details about the capybara male reproductive physiology were elucidated by Paula (1999), Paula et al. (1999) and Costa et al. (2002). Some of the most interesting aspects of the spermatogenic process is the high number of Leydig cells, which account for around one third of the testicular parenchyma and the distribution and proportion of the components of the lymphatic space in the intertubular compartment.

In view of the increasing interest in the commercial breeding of this species and the peculiar constitution of the testicular parenchyma, this work aimed to correlate testosterone levels with the nasal gland volume and Leydig cell morphometry in the testicular parenchyma of sexually mature capybaras.

\section{MATERIALS AND METHODS}

Ten adult capybaras selected for the Pro Fauna slaughterhouse, in Iguape-SP, were used in this study. Immediately after slaughter, the animals were weighed and testes were collected, separated from epididymis and weighed.

One of the testis was initially perfused for 10 to 15 minutes, through the testicular artery, with $0.9 \%$ saline solution containing $125 \mathrm{IU} /$ liter heparin, and then perfused-fixed with $3 \%$ glutaraldehyde in $0.1 \mathrm{M}$ phosphate buffer $(\mathrm{pH}$ 7.4). To maintain a pressure of around $80 \mathrm{mmHg}$, the tubes containing the perfusion solutions were kept at a height of $120 \mathrm{~cm}$ (Russell et al., 1990).

The fragments of testicular parenchyma were immersed in a glutaraldehyde solution and kept at $4^{\circ} \mathrm{C}$ until being processed. The material was included in a glycol metacrylate solution, according to routine technique, and $4.0 \mu \mathrm{m}$ sections were prepared and stained with toluidin blue.

The volume density of Leydig cells in the testicular parenchyma was evaluated by light microscopy, with the help of a square $10 \mathrm{~mm} / 100 \mathrm{sq}$ micrometric reticulum, enhanced with 110 points/400x (Costa et al., 2004). The average diameter of Leydig cell nuclei was determined through the analysis of 20 cells/animal, with the help of a square $10 \mathrm{~mm} / 100 \mathrm{sq}$ micrometric reticulum. With the formula $4 / 3 \pi r^{3}$, being $r$ the average nuclear radius, nucleus volume was determined, allowing also the calculation of the average cell volume. The number of Leydig cells per testis and per gram of testis could thus be determined.

The gonodasomatic index (GSI) was calculated according to Paula (1999). The leydigosomatic 
index was determined by multiplying the percentage of body, represented by the two testes, and the percentage of testis, represented by Leydig cells, and dividing the result by 100 .

The age of the animals was estimated from the weight of the dry crystalline, in milligrams (Paula, 1999). This is possible because the crystalline is an ectodermic structure, whose components present continuous growth throughout life (Friend, 1968; Morris, 1972), so that the weight is proportional to the age of the animal. The regression analysis model developed by Moreira (1995), $\mathrm{L}=53.9528 \mathrm{X}^{0.451588}$, being $\mathrm{L}$ $=$ dry crystalline average weight in milligrams and $\mathrm{X}=$ animal age in months, was used. The procedure involved enucleation of the animals after slaughtering and immediate collection of the crystallines with the help of scissors. The crystallines were dehydrated by maintenance at $60^{\circ} \mathrm{C}$ for three days, in glass containers properly identified and weighed.

The nasal gland volume was determined by measuring length, width and thickness with the aid of pachimetter. Thickness was estimated from three measurements made at points equidistant to a longitudinal sectioning of the medium line of the gland. The following formula was used: volume $=(1 / 2) \times(4 / 3) \pi \times A B C$, being $\mathrm{A}=$ half of the length, $\mathrm{B}=$ half of the width and $\mathrm{C}=$ nasal gland thickness (Moreira, 1995).

Serum testosterone levels were determined from blood samples collected from the jugular vein. Blood was centrifuged at 3,500rpm for 20 minutes and the serum was frozen for posterior analyses. Serum testosterone levels were determined by solid phase radioimmunoassay ( ${ }^{125}$ I RIA ICN Biomedicals), using a Gamma counter, according to the manufacturer instructions.

The results were evaluated with the help of the Excel for Windows software, and expressed as average \pm standard deviation. Correlation analyses were carried out according to Sampaio (1998)

\section{RESULTS}

Body weight varied from 45.0 to $54.4 \mathrm{~kg}$, average age was around 28 months and average testicular weight was approximately $28.0 \mathrm{~g}$. The sum of weight from both testes, divided by the body weight for each animal, allowed estimation of the gonodosomatic index (GSI), which was on average around $0.1 \%$.

The nasal gland was very evident in all the animals, with an average volume of approximately $34.0 \mathrm{ml}$. The sebaceous secretion which characterizes this gland was observed in all animals composing the experimental groups. Average serum testosterone level was about $25.0 \mathrm{ng} / \mathrm{ml}$. For this parameter the coefficient of variance was $58.7 \%$.

A positive and significant correlation between nasal gland volume and serum testosterone levels was found in the capybaras $(\mathrm{r}=0.94 ; \mathrm{P}<0.01)$. Nasal gland volume also correlated positively and significantly with the leydigosomatic index $(\mathrm{r}=0.79 ; \mathrm{P}<0.05)$, with Leydig total cell numbers $(\mathrm{r}=0.82 ; \mathrm{P}<0.05)$ and with Leydig cell total volume per testis $(\mathrm{r}=0.79 ; \mathrm{P}<0.05)$. However, the correlation between nasal gland volume and animal age was not significant $(\mathrm{r}=0.18 ; \mathrm{P}>0.05)$.

Serum testosterone levels presented a positive and significant correlation with the individual volume of Leydig cells $(\mathrm{r}=0.76 ; \mathrm{P}<0.05)$. However, no significant relationship was observed with Leydig cell number per testis $(\mathrm{r}=0.66 ; \mathrm{P}>0.05)$, Leydig cell number per gram of testis $(r=-0.09, \mathrm{P}>0.05)$, or with Leydig cell volumetric proportion in the testicular parenchyma $(\mathrm{r}=0.11 ; \mathrm{P}>0.05)$.

The intertubular compartment was mainly composed of abundant groups of Leydig cells, extensive lymphatic sinusoids and a small area of connective tissue. Leydig cells represented around $30 \%$ of the testicular parenchyma (Table 1 ), which generated a leydigosomatic index of about $0.03 \%$. The individual and total volume of Leydig cells were around $2,230 \times 10^{-12}$ and $6.9 \mathrm{ml}$, respectively. 
Table 1. Serum testosterone levels, hystometric and biometric parameters of adult capybara testis

\begin{tabular}{|c|c|}
\hline Characteristic & Mean \pm SD \\
\hline Age (months) & $28.34 \pm 3.41$ \\
\hline Body weight (kg) & $50.50 \pm 3.37$ \\
\hline Testis weight (g) & $27.83 \pm 6.54$ \\
\hline Gonadosomatic index (\%) & $0.11 \pm 0.02$ \\
\hline Nasal gland volume (ml) & $34.12 \pm 13.04$ \\
\hline Testosterone concentration (ng/ml) & $25.07 \pm 14.73$ \\
\hline Leydig cell volume density (\%) & $28.76 \pm 8.33$ \\
\hline Leydigosomatic index $(\%)$ & $0.030 \pm 0.007$ \\
\hline Leydig cell volume per testis $(\mathrm{ml})$ & $6.88 \pm 1.92$ \\
\hline Leydig cell volume $\left(\mathrm{x} 10^{-12} \mathrm{ml}\right)$ & $2,228.14 \pm 272.59$ \\
\hline Leydig cell number per testis $\left(\times 10^{6}\right)$ & $3,079.40 \pm 719.90$ \\
\hline Leydig cell number per gram of testis $\left(\times 10^{6}\right)$ & $115.09 \pm 31.78$ \\
\hline
\end{tabular}

\section{DISCUSSION}

Body weight and age of the animals used in this study presented low variation, validating the uniformity of the experimental group. These values, added to the fact that nasal glands were present in all capybaras, characterized the group as sexually mature (Costa et al., 2002).

The gonadosomatic index was very similar to that found by Paula (1999) and inferior to that reported by Moreira et al. (1997), who observed an index of $0.14 \%$ in a group of 100 adult capybaras. In this study, however, GSI was calculated by weighing testes with epididymis, which resulted in an overrated index.

Considering that nasal gland size is directly proportional to the hierarchical position occupied by males in the social group (Herrera, 1992), the average volume of nasal glands observed suggests that the animals included in this study were the dominant males in the family group.

Although some researchers have described a positive and significant correlation between nasal gland volume and age (Herrera, 1992; Paula, 1999), the relationship between these two variables was not significant in the present work. This could be due to the smaller number of animals investigated. However, when the group is increased by adding the capybaras studied by Paula (1999), presenting the same age of the animals included in this work (between 24.8 and 33.4 months old, $\mathrm{n}=10$ ), no significant correlation between age and nasal gland volume was found. Therefore, the suggestion of Herrera
(1992) that older animals tend to have larger nasal glands seems to be true for animals up to 25-month-old. From then on, the increase in gland volume did not follow ageing. That seems reasonable, since after reaching sexual maturity the male still continues to gain weight and obviously gets older, but testosterone levels, sexual development and other reproductive parameters are stabilized (Amann and Schanbacher, 1983).

Similarly to the findings of Paula (1999) and Costa et al. (2002), these results showed that the volume density of Leydig cell in testis in capybaras surpasses that observed in any other mammal. Likewise, individual and total volume, as well as Leydig cell number per testis, represent some of the largest values reported for mammals. The values reached by these parameters suggest that in capybaras there is a great investment in androgenic production to assure family group hierarchy, since the dominant male is extremely aggressive with other individuals of the same sex (Alho, 1986).

The relationship between nasal gland volume and testosterone levels, until now just speculative, was confirmed in this research. These variables present a positive and significant correlation, that is, higher serum testosterone levels are accompanied by a proportional increase of nasal gland volume. This explains the fact that the volume of nasal gland begins to increase with puberty (Herrera, 1992). However, testosterone levels did not correlate with age in the present work. This could be explained by the fact that only sexually mature animals, a phase in which 
the Leydig cell population is stable (Hardy et al., 1989), were used. A positive and significant correlation would be expected if the investigated group included pre-puberty, post-puberty and sexually mature animals as reported for other mammalian species (Lapwood and Florcruz, 1978; Sharma et al., 1984; Santos et al., 2000).

Some researchers have tried to determine the mechanisms involved in the great variation in testosterone levels observed among different species. Ewing et al. (1979), using morphometric techniques, concluded that different testosterone levels were not related to the volumetric proportion occupied by Leydig cells in testis in different species. In the following year, a study of Leydig cell ultra-structure by the same research group (Zirkin et al., 1980) showed that one of the factors highly related $(\mathrm{r}=0,99)$ with variation in testosterone production among different species seemed to be the area occupied by the smooth endoplasmic reticulum in the cytoplasm.

These results support these findings. Testosterone levels were not significantly correlated with the proportion of Leydig cells or with Leydig cell numbers per testis in the studied animals. These findings suggest that, in capybaras, the rates of testosterone production vary according to parameters that do not depend on the number or proportion of Leydig cells in the testis.

On the other hand, a positive and significant correlation between testosterone levels and the individual volume of Leydig cells was observed. This result supports the report by Ewing et al. (1979), showing that the production of steroids in each species, to attend specific needs, is more related to the capacity of individual Leydig cells to secrete particular hormones than to population and volumetric criteria. Although an ultrastructural analysis of capybara Leydig cells was not performed in the present work, the results support the hypothesis that larger cell volumes are associated to larger smooth endoplasmic reticulum volumes, and in consequence to the capacity for increased levels of testosterone production.

In conclusion, the results of this study show that increased serum levels of testosterone in capybaras are related to a proportional increase in the volume of nasal glands, and that hormone concentration is positively correlated with Leydig cell volume.

\section{REFERENCES}

ALHO, C.J.R. Criação e manejo de capivaras em pequenas propriedades rurais. Dep. de Difusão de Tecnologia, Brasília, DF- Embrapa, 1986. 33p.

AMANN, R.P.; SCHANBACHER, B.D. Physiology of male reproduction. J. Anim. Sci, v.57, suppl., p.380-403, 1983.

COSTA, D.S.; HENRY, M.; PAULA, T.A.R. Espermatogênese de catetos (Tayassu tajacu). Arq. Bras. Med. Vet. Zootec., v.56, p.46-51, 2004.

COSTA, D.S.; PAULA, T.A.R.; FONSECA, C.C. et al. Reprodução de capivaras. Arq. Cien. Vet. Zool. Unipar., v.5, p.111-118, 2002.

EWING, L.L.; ZIRKIN, B.R.; COCHRAN, R.C. et al. Testosterone secretion by rat, rabbit, guinea pig, dog and hamster testes perfused in vitro: correlation with Leydig cell mass. Endocrinology, v.105, p.1135-1142, 1979.

FRIEND, M. The lens technique. Trans. N. Am. Wildl. Conf., v.33, p. 279-298, 1968.

HADLEY, M.E. Endocrinology. 2.ed. New Jersey: Prentice Hall, 1988. 549p.

HARDY, M.P.; ZIRKIN, B.R.; EWING, L.L. Kinetic studies on the development of the adult population of Leydig cell in testes of the purbertal rat. Endrocrinology, v.124, p.762-770, 1989.

HERRERA, E.A. Size of testes and scent glands in capybaras (Hydrochoerus hydrochaeris Rodentia : Caviomorpha). J. Mamm., v.73, p.871-975, 1992.

LAPWOOD, K.R.; FLORCRUZ, S.V. Luteinizing hormone and testosterone secretory profiles of boars: Effects of stage of sexual maturation. Theriogenology, v.10, p.293-306, 1978.

LAVORENTI, A. Domestication and potential for generic improvement of capybara. Rev. Bras. Gen., v.2, p.137-144, 1989.

MOREIRA, J.R. The reproduction, demography and management of capybaras (Hydrochaeris hydrochaeris) on Marajó Island - Brazil. 1995. Thesis (Doctorate) - University of Oxford, England.

MOREIRA， J.R.; MACDONALD， D.W.; CLARKE, J.R. Correlates of testis mass in capybaras (Hydrochoerus hydrochaeris): 
dominance assurance or sperm production? J. Zool, v.241, p.457-463, 1997.

MORRIS, P. A review of mammalian age determination methods. Mamm. Rev. v.2, p.69-104, 1972.

O'DONNEL, L.; ROBERTSON, K.M.; JONES, M.E. et al Estrogen and spermatogenesis. Endocrinol. Rev., v.22, p.280-318, 2001.

PARRA, R.; ESCOBAR, A.; GONZALEZJIMÉNEZ. E. El chigüire o capibara (Hydrochoerus hydrochaeris), 1. Ganancia de peso y eficiencia de conversion de alimentos. Mem. ALPA, v.13, p.93, 1978.

PAULA, T.A.R. Avaliação histológica e funcional do testículo de capivaras adultas (Hydrochoerus hydrochaeris). 1999. 84f. Tese (Doutorado) Escola de Veterinária, Universidade Federal de Minas Gerais, Belo Horizonte.

PAULA, T.A.R.; CHIARINI-GARCIA, H.; FRANÇA, L.R. Seminiferous epithelium cycle and its duration in capybaras (Hydrochoerus hydrochaeris) Tissue Cel., v.31, p.327-334, 1999.

RUSSELL, L.D.; ETTLIN, R.A.; SINHA-HIKIM, A.P. et al. Histological and histopathological evaluation of the testis. Clearwater, Fla: Cache River, 1990. 286p.
SAMPAIO, I.B.M. Estatística aplicada à experimentação animal. Belo Horizonte: FEPMVZ, 1998. 221p.

SANTOS, M.D.; TORRES, C.A.A.; RUAS, J.R.M. et al. Concentração sérica de testosterona em touros zebu. Rev. Bras. Zootec., v.29, p.738-744, 2000.

SECTHELL, R.M. Male reproductive organs and semen. In: CUPPS, P.T. (Ed). Reproduction in domestic animals. 4.ed. San Diego: Academic, 1991. p.221-250.

SHARMA, I.J.; AGARWAL, S.P.; AGARWAL, V.K. et al. Changes in profiles of serum sex steroids of male buffaloes from birth to maturity. Theriogenology, v.22, p.175-186, 1984.

SILVA NETO, P.B. Alimentação e manejo de capivaras (Hydrochoerus hydrochaeris hydrochaeris L. 1766) em cativeiro. 1989. 99p. Dissertação (Mestrado) - Escola Superior de Agricultura Luiz de Queiroz, Universidade de São Paulo, Piracicaba, SP.

ZIRKIN, B.R.; EWING, L.L.; KROMANN, N. et al. Testosterone secretion by rat, rabbit, guinea pig, dog, and hamster testes perfused in vitro: correlation with Leydig cell ultrastructure. Endocrinology, v.107, p.1867-1874, 1980. 